Table 2. Prophylactic experiments in mice infected with $T$. congolense

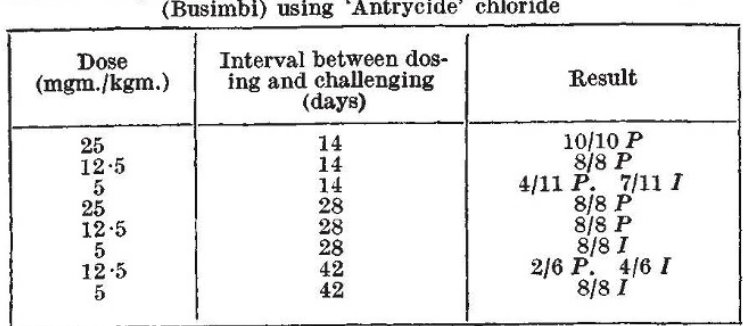

Our laboratory results appeared to us to justify field trials, and in association with the Tsetse Fly and Trypanosomiasis Committee of the Colonial Office, and with the Sudan Government, veterinary trials were commenced in Africa. Although these trials are still incomplete, the evidence already available shows that 'Antrycide' salts may be administered subcutaneously with ease and safety and, in single doses, have cured infections of $T$. congolense, $T$. vivax and $T$. brucei in cattle, $T$. bruce $i$ in horses, donkeys and dogs and T. evansi in camels. 'Antrycide' salts have also been shown by us to give considerable protection to cattle against subsequent infection with $T$. congolense and $T$. vivax. Experiments are still in progress to determine the duration and the character of this prophylactic action, and to ascertain whether the drugs can be used successfully for the protection of cattle maintained in or transported through tsetse areas of tropical Africa. The good correlation obtained so far between laboratory and field results encourages us to expect prophylactic effects of importance.

\section{川 OBITUARIES}

\section{Dr. F. H. S. Curd}

THE tragic death on December 2 of Francis Henry Swinden Curd, following injuries received a few days earlier in a raikway fecident, robs chemotherapeutic research of one ol its foremost workers, and at an age when his'quałties were approaching full fruition.

Born in 1909, he received his early education at Bancrofts School, Woodford. Passing to East London College (Queen Mary College), he graduated in the

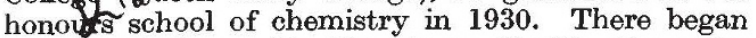
his association with Dr. (now Prof.) Alexander Robertson, with whom he remained when the latter was appointed to the London School of Hygiene and Tropical Medicine. Until 1933 he collaborated in researches on the synthesis of compounds related to the lichen acids, for which he gained his Ph.D. Although this work did not bear directly on the chemotherapy of tropical diseases, there is little doubt that his interest in this subject was first aroused during the years spent at the London School.

In 1933 he entered the research laboratories of Imperial Chemical Industries, Ltd., at Blackley, Manchester, and like many earlier workers in the field of chemotherapy, served his apprenticeship on an investigation of the chemistry of dyestuffs. Some part of his time, however, was given to a continuation, with Mr. S. Ellingworth, of the studies on the styrylquinoline series of trypanocidal drugs which the latter worker had earlier begun with Prof. J. B. Cohen. In 1936, he was seconded to the newly formed Medicinal Chemicals Section, and for the next three years devoted his full attention to trypanosomiasis.
The shadow of approaching war caused this work to be interrupted, and Curd began the task of devising routes to the German synthetic antimalarial drugs, 'Atebrin' ('Mepacrine') and 'Plasmochin' ('Pamaquin'). Despite the lack of published information on preparative methods, these problems were solved during 1939, and his work laid the foundation for a largescale manufacture, particularly of 'Mepacrine', at that phase of the War when the drug was most urgently needed.

Experience with this substance indicated its shortcomings and, as in other parts of the world, stimulated the search for more effective agents. Curd was again entrusted with this task, and he began by making an exhaustive study of the existing extensive literature on the chemotherapy of malaria (Ann. Trop. Med. and Parasit., 1943) which stands as a model of what such a survey should be. His attention was aarly directed to the pyrimidine nucleus as the basis for new synthesis, and with his colleagues he rapidly developed entirely new chemotherapeutic types which culminated in the preparation, in 1944, of the diguanide 'Paludrine'. For his part in this work he was awarded in 1947, jointly with D. G. Davey and F. L. Rose, the Gold Medal for Chemotherapy of the Worshipful Society of Apothecaries.

More recently, Curd's attention had turned again to the problem of trypanosomiasis; and although he died before seeing the completion of his new work, there is little doubt that the outcome of his later researches, when fully revealed in the results of fieldtrials now in progress in Africa, will mark him as an outstanding figure in chemotherapeutic research, and will emphasize the national significance of his loss. [A preliminary account, with Dr. D. G. Davey, appears on p. 89.-EDIToRs.]

Curd's personal attributes were known to a wide circle of friends in industry, universities and research institutions. A natural gentleman, at all times charming and modest, he was characterized by meticulous care in all he did, and by an enthusiasm which inspired everyone with whom he came in contact. $\mathrm{He}$ leaves a widow and three young daughters.

\section{F. L. Rose}

By the death of F.H. S. Curd the science of chemotherapy has lostan outstanding contributor. In the years he devoted to the chemotherapy of the parasitic diseases, CPad, and hiq es-workers achieved results the scientifil and practical importance of which have not been surpassed in this field. That the investiga. thn in which he was engaged proceeded with smoothness and certainty was largely due to Curd's personal qualities. His sound common sense, well-developed critical faculties, and an unassuming wealth of know. ledge allied to remarkable technical ability ensured the hearty co-operation of his associates, chemical, biological and medical, and promoted the directional stability of the investigations in which he played so prominent a part. His place will indeed be difficult to fill.

A. R. D. Adams

WE regret to announce the following deaths :

Mr. J. H. Coste, chemist-in-chief of the London County Gouncil during 1913-36, on January 3, aged seventy-seven.

Mr T. Petch, formerly Government mycologist, Ceylon, later director of the Ceylon Tea Research Institute, on December 24, aged seventy-eight. 